\title{
THE ROLE OF SPLEEN MACROPHAGES IN MALARIA: AN ULTRASTRUCTURAL STUDY ${ }^{1}$
}

\author{
Carlos Eduardo Tosta2, Greta Ruiz and Nina Wedderburn
}

\begin{abstract}
An electronmicroscopy study of the spleen from mice infected with Plasmodium berghei was carried out to investigate the types of cells involved in the removal of parasites from the blood, and the mechanisms by which this occurs. Macrophages, particularly from the red pulp and the marginal zone of the spleen, constituted the most important population of phagocytic cells in the spleen. At the height of parasitaemia, macrophages in the periphery of the white pulp, especially in the mantle zone of secondary follicles, were also found to participate in phagocytosis, although to a limited extent. Our findings suggest that phagocytosis of free parasites or parasitized erythrocytes in the spleen is an important mechanism of clearance of parasites from the circulation. Parasites removed from the erythrocytes when these cells cross the interendothelial slits are further phagocytosed by neighbouring macrophages. Evidence is presented suggesting that spleen macrophages may act against the parasite through a process of cytotoxicity.
\end{abstract}

Key words: Malaria. Plasmodium berghei. BALB/c mice. Spleen. Macrophages. Phagocytosis. Cytotoxicity.

The predominantly intraerythrocytic habitat of malarial parasites and the fact that gross changes in the splenic microarchitecture occur during malaria ${ }^{8} 15$, make the spleen an important organ in which to study host - parasite interactions. At this site parasites are removed from the blood, phagocytosed, and both induce and are subjected to the effects of the immune response. Although macrophages play a central role in all these events, our understanding of their functions is still very fragmentary and several important questions remain unanswered. This study was therefore undertaken to investigate the nature of phagocytic cells from different areas of the spleen during malaria infection, and the mechanisms by which they remove parasites from the blood.

\section{MATERIALS AND METHODS}

Four month old female BALB/c mice were infected intravenously with $10^{5} \mathrm{P}$. berghei (Anka

1. From the Department of Pathology, Royal College of Surgeons of England, London, England.

2. Present address and address for correspondence: Laboratório de Imunologia Celular, Departamento de Medicina Complementar, Universidade de Brasilia, 70910 Brasilia, DF, Brazil.

Recebido para publicação em 30/11/1983. strain) - infected erythrocytes, and eight days later, anesthetized by ether 30 minutes after an injection of 150 units of heparin intravenously. A polythene cannula ( $0.61 \mathrm{~mm}$ external diameter) was inserted caudally into the thoracic aorta and its tip secured at the level of emergence of the coeliac artery. After clamping the distal aorta and sectioning the portal vein, animals were perfused with phosphate buffered saline at $37^{\circ} \mathrm{C}$ at a pressure of $163 \mathrm{~cm}$ of water. After bleaching of the liver, perfusion was switched to the fixation solution of $1.5 \%$ glutaraldehyde in $0.1 \mathrm{M}$ sodium cacodylate buffer $\mathrm{pH} 7.3$. Spleens were removed after 15 min perfusion with the fixative, sliced into sections of $1 \mathrm{~mm}$ submitted to a further 2 hour fixation with $4 \%$ buffered glutaraldehyde and washed with cacodylate buffer containing $10 \%$ sucrose. Tissues were post fixed in veronal-acetate buffered $1 \%$ osmium tetroxide, dehydrated in ethanol, embedded in Araldite and stained with uranyl acetate and lead citrate, and examined by electron microscopy.

Areas comprising each major cell compartment of the spleen (red pulp, marginal zone, periarteriolar lymphocyte sheath and germinal centre) were selected in toluidine blue-stained sections, and relocated on the surface of the corresponding block. Phagocytic cells were characterized by the presence of ingested parasites or malarial pigment. The latter was recognized as osmiophilic trapezoidal crystals, sometimes partially dissolved by the lead citrate used for processing the tissue. 
Tosta CE, Ruiz G, Wedderburn $N$. The role of spleen macrophages in malaria: an ultrastructural study. Revista da Sociedade Brasileira de Medicina Tropical 17: 31-36, Jan-Mar, 1984

\section{RESULTS}

\section{Phagocytic cells in the spleen}

Macrophages from the red pulp, marginal zone and sinus, mantle zone and germinal centre, participated to different degrees in the process of phagocytosis of malarial parasites. Red pulp macrophages appeared to be the most active population of phagocytic cells in the spleen. They possessed an abundant cytoplasm, rich in membrane-bound vacuoles and lysosomes, and frequently displaying a ruffled plasma membrane (Fig. 1). Red pulp macrophages were usually actively engaged in phagocytosis and contained debris of ingested parasites.

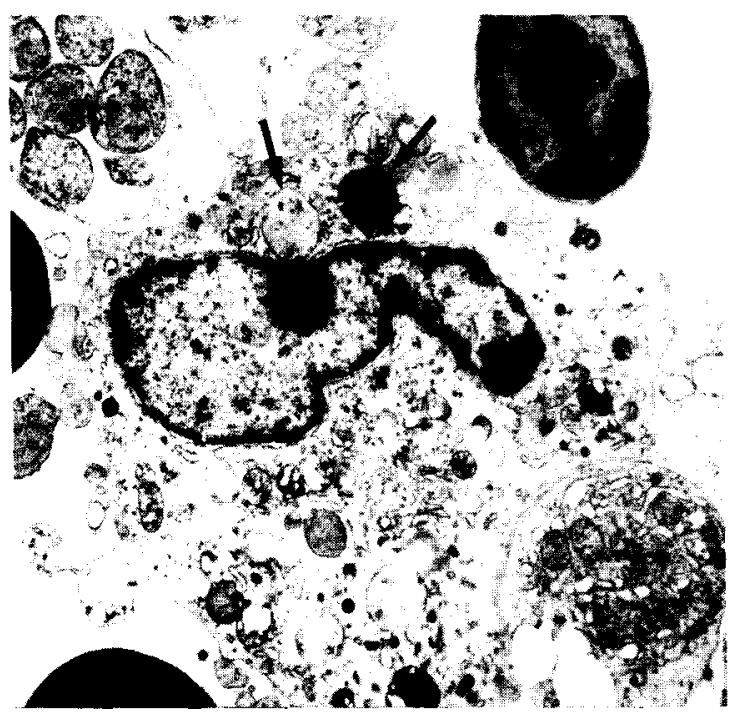

Figure 1 - A red pulp macrophage, which contains debris of ingested parasites (arrows), in physical contact with some "phagocytosable" particles; including parasitized and nonparasitized erythrocytes, a damaged cell and the extruded nucleus of a normoblast. X4, 700 .

Marginal zone macrophages represented another important population of splenic phagocytic cells. They were large cells usually possessing an irregular shape and exhibiting an array of ingested particles, including parasites (Fig. 2). They were characteristically observed in physical contact with lymphocytes and some of the latter were seen to be in the process of cell division (Fig. 3).

The marginal sinus was another site where macrophages active against malaria were observed. They were usually seen free in the circulating blood, and they also presented an abundant cytoplasm rich in lysosomes and ingested material, and ruffled plasma membrane. On a number of occasions, marginal sinus macrophages were found firmly attached to endothelial

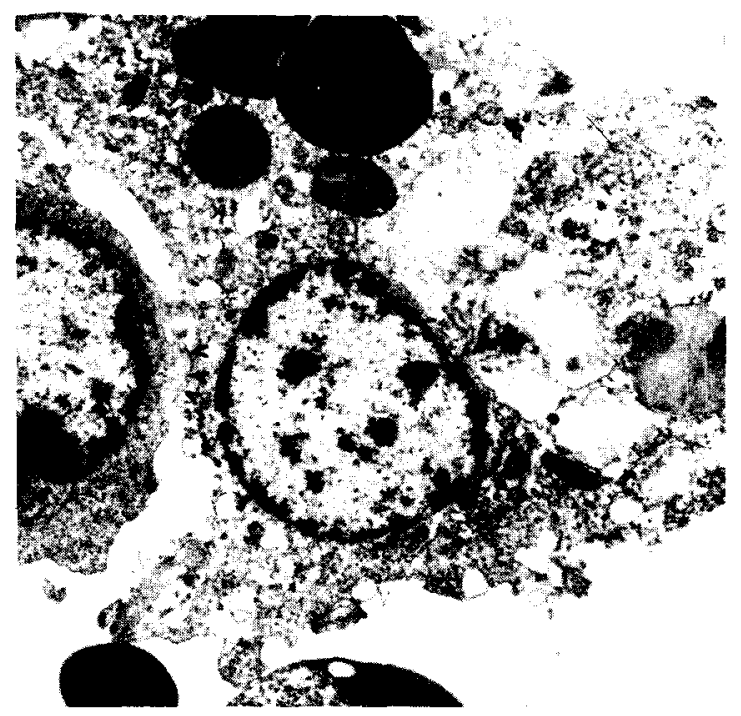

Figure 2 - Marginal zone macrophage showing attached and ingested $P$. berghei - parasitized erythrocytes. Its plasma membrane is closely associated with that of a lymphocyte (arrow heads) X4, 000.

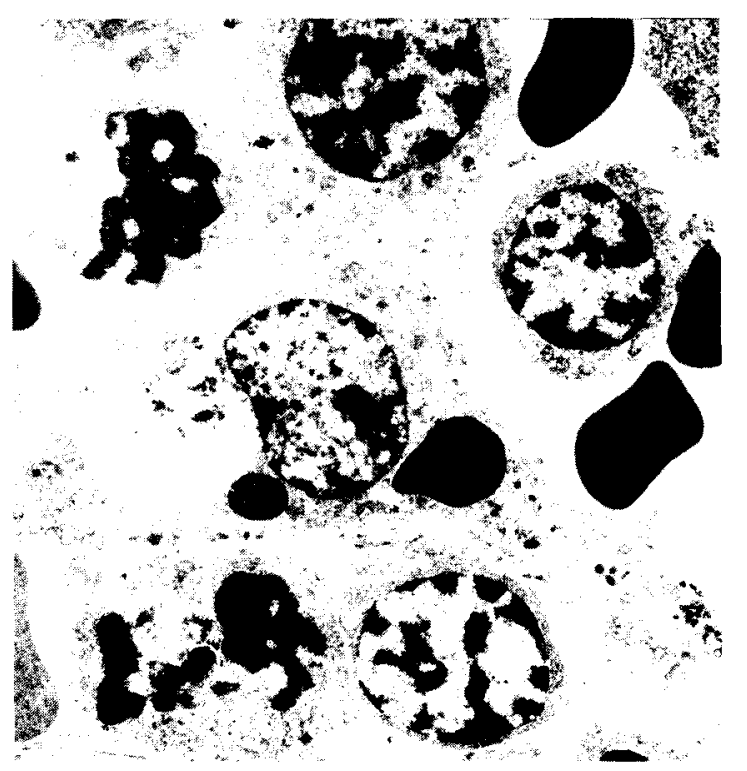

Figure 3 - A cluster formed by a marginal zone macrophage showing signs of active phagocytosis and several lymphocytes, two of them in the process of cell division. X5, 700 . 
Tosta CE, Ruiz G, Wedderburn N. The role of spleen macrophages in malaria: an ultrastructural study. Revista da Sociedade Brasileira de Medicina Tropical 17: 31-36, Jan-Mar, 1984

cells lining the sinuses (Fig. 4). Although no desmosome-like structure were observed, suggesting that this association was transient, an electron-dense material was invariably present at the surface of contact between the cells.

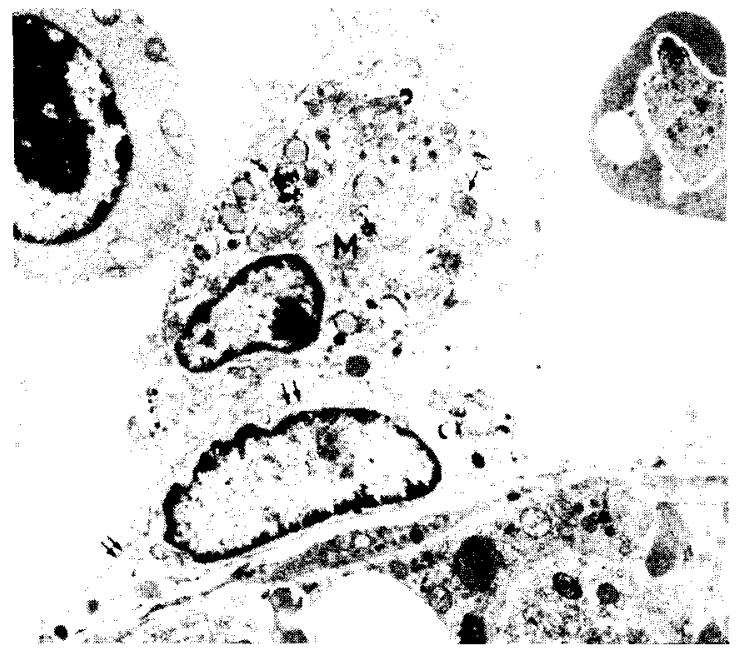

Figure 4 - A macrophage (M) in the marginal sinus containing debris of ingested parasites (arrows), firmly attached to an endothelial cell. Note the presence of electron-dense material at the surface of contact between the cells (double arrows). An erythrocyte precursor is attached to the macrophage, while a parasitized erythrocyte is seen nearby. X3, 600 .

Germinal centre (tingible body) macrophages did not seem to phagocytose malaria parasites, although they were found loaded with ingested nucleated cells. Macrophages containing parasitic material were only occasionally seen in the mantle zone of the white pulp. Although macrophages were by far the most active population of phagocytic cells in the spleen, other cells also appeared to play a role in the clearance of parasites, including reticular cells, interdigitating cells, endothelial cells and eosinophils. Reticular cells were found particularly in the periphery of the white pulp, either alongside the sinuses, in contact with the basement membrane or as part of the stroma, and were frequently associated with deposits of reticulin or collagen. They were identified by their electron-dense nucleoplasm and cytoplasm matrix. Such cells sometimes contained debris of ingested parasites. Interdigitating cells were observed in the periarteriolar lymphocytic sheaths and were characterized by their large size, stellate shape, and the typically electronlucent cytoplasm presenting tubulo-vesicular structures. These cells characteristicaly possessed cytoplasmic projections interdigitating with neighbouring lympho- cytes, and were sometimes pierced by finger-like protrusions of the latter cells (Fig. 5). Some interdigitating cells displayed ingested parasites in an advanced stage of digestion. Eosinophils and sinusoidal endothelial cells also very occasionally contained phagocytosed parasites.

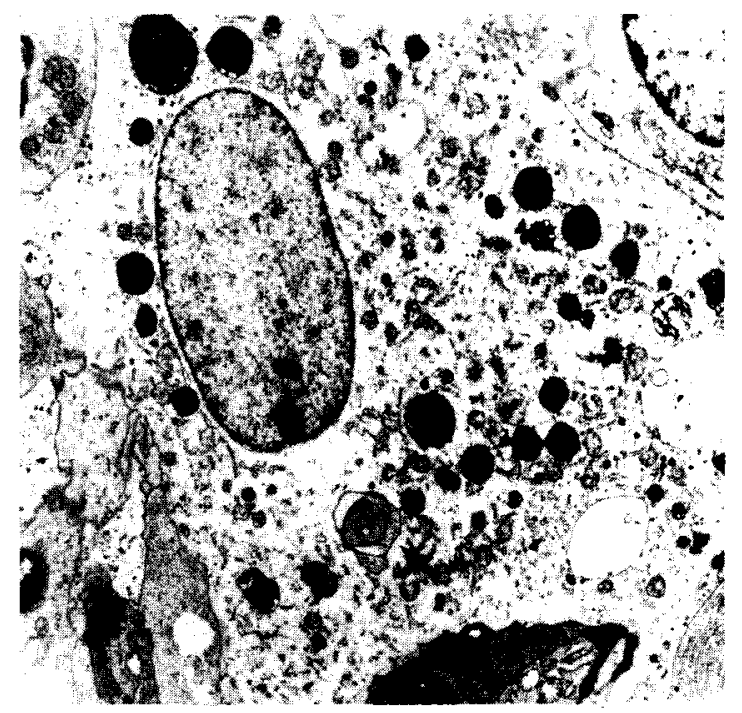

Figure 5 - Interdigitating cell containing cell debris and malarial pigment. Cytoplasmic projections interdigitate with neighbouring lymphocytes and a fingerlike cell protrusion (arrow) pierces the cytoplasm. X2, 700 .

\section{Macrophages and the removal of parasites}

Phagocytosis appeared to be an important functions of spleen macrophages. Malaria parasites were removed from the circulation either as parasitized erythrocytes in toto or as free parasites. This "culling" function is performed chiefly by red pulp macrophages and, to a lesser degree by marginal zone phagocytic cells. However, parasites may also be removed from erythrocytes during the passage of these cells across the interendothelial slits of the sinusoidal wall and are probably subsequently phagocytosed by nearby macrophages (Fig. 6). This process appeared to take place mainly in the marginal zone, but also occurred in the red pulp.

During the infection, parasitized and non-parasitized erythrocytes were found packed in the marginal zone meshwork. They were apparently in the process of undergoing lysis, enabling the freed parasites to be phagocytosed by macrophages lying in the vicinity 
Tosta CE, Ruiz $G$, Wedderburn $N$. The role of spleen macrophages in malaria: an ultrastructural study. Revista da Sociedade Brasileira de Medicina Tropical 17: 31-36. Jan-Mar, 1984

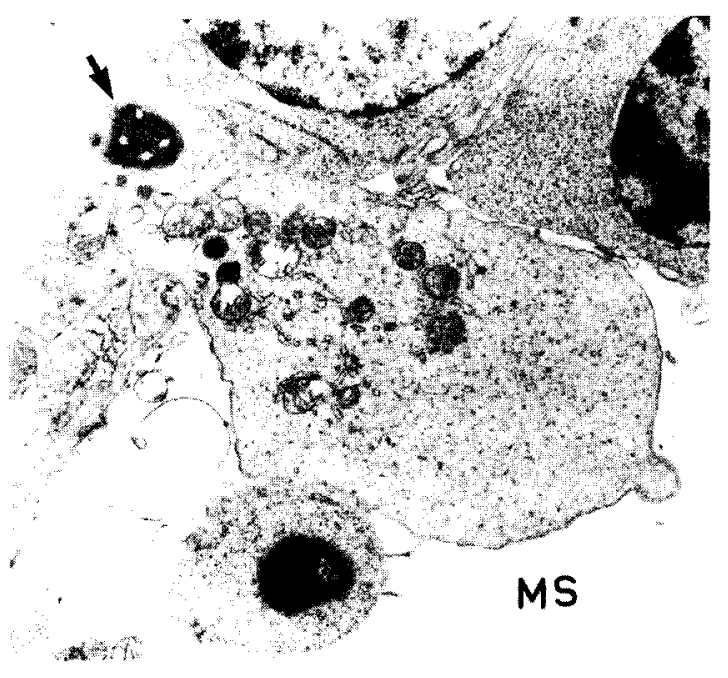

Figure 6 - A reticulocyte crossing an aperture between two endothelial cells, halfway to the marginal sinus (MS). The tail of the reticulocyte exhibits an inclusion (arrow) possibly a parasite. X5, 400 .
(Fig. 7). Intraerythrocytic parasites also showed signs of structural alteration, particularly when they were in close proximity to macrophages.

\section{DISCUSSION}

The crucial role of the spleen for resolution of malaria infection is well established and has been the subject of recent reviews 1819 . In different models, splenectomy may result in a fulminant course of the infection. Our data and the results from other workers 17 suggest that spleen macrophages perform a critical role in spleen-dependent protection. They can act as phagocytic cells, as cytotoxic cells and as cells involved in the process of induction and regulation of the immune response against malaria parasite.

Parasitized erythrocytes enter the spleen via the small branches of the central arteriole, most of which terminate in the marginal zone ${ }^{1}$. From the marginal zone and marginal sinus these cells circulate through

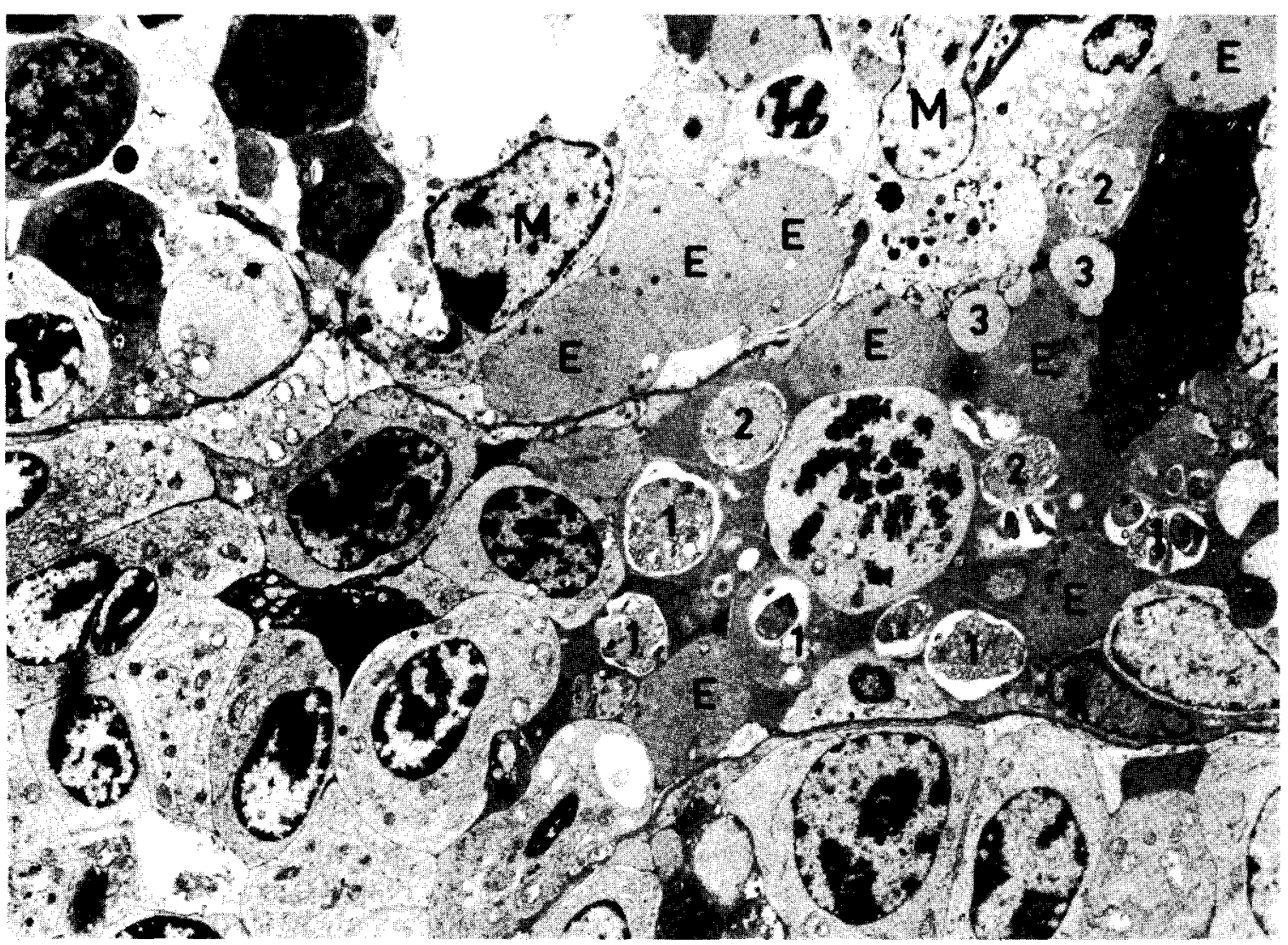

Figure 7 - Erythrocytes (E) packed in the marginal zone cords. The cells are swollen and their outlines not clearly distinguishable. Intraand extracellular parasites show diferent degrees of structural alteration, varying from a fairly normal appearance (1) to a completely blurred structure (3), with some intermediate forms (2). Macrophages (M) are seen in the vicinity. X2, 400 . 
the red pulp, entering the sinuses, and finally leaving the organ by a vein. During this course parasitized erythrocytes are submitted to the "culling" function of the macrophages of the marginal zone and the red pulp cords. As a result, free and intraerythrocytic parasites are "recognized" by macrophages and subsequently phagocytosed. There is evidence that this function is significantly increased about the time antibodies against the parasite are detected ${ }^{12}$. The opsonizing activity of antimalarial antibodies is well established 511 , and this is at least in part due to the presence of antibodies cytophilic for macrophages ${ }^{14}$.

To enter the sinuses in the marginal zone and red pulp, the erythrocytes have to cross the small apertures between the endothelial cells, which are estimated to be aproximately $0.5-2.5 \mu \mathrm{m}$ wide ${ }^{3}$. While normal erythrocytes are able to squeeze through these slits, parasitized erythrocytes not only take longer, but also they may be severed, the part containing the parasite being trapped on the cordal side and eventually phagocytosed. The part of the erythrocyte which bears no parasite may reach the sinusoidal side and return to the circulation either as a spherocyte ${ }^{9}$, or as an atypical reticulocyte, showing extensive structural alterations ${ }^{13}$, depending whether the "deparasitized" cell was a mature or an immature erythrocyte.

During the crossing through the spleen, erythrocytes are submitted to rheological and metabolic hazards. During the course of infection these hazards are considerably accentuated. As a result of the splenomegaly the vascular pathway becomes extended and more tortuous, which play an important part in the genesis of stasis. Stasis causes a relative anoxia, which leads to a decrease in the glucose content of erythrocyte $^{16}$. It is possible to speculate that this may cause some limitation to the growth of the highly glucose consuming plasmodium. Another consequence of the lowering of the intraerythrocytic content of glucose is the necessity for anaerobic utilization of glucose, which leads to a fall in the intrasplenic $\mathrm{pH}$, and hence a shift in the oxygen disscciation curve of haemoglobin. This results in a further decrease of oxygen tension, causing marked rigidity of the erythrocytes 6 , making them less deformable and, consequently, less able to cross the fenestrations of the sinusoidal wall. As a result erythrocytes - parasitized, non-parasitized and "deparasitized" - take longer for this crossing, which further aggravate the already existing stasis and causes sequestration of the cells. This provide a possible explanation for our finding of erythrocytes, packed in the periphery of the white pulp, and showing signs of pre-lysis. At this site intraerythrocytic parasites also displayed an array of ultrastructural alteration. The close proximity of these altered cells to macrophages showing signs of activation strongly suggests that these latter cells may be releasing some toxic products, perhaps oxygen radicals or tumour necrosis factor ${ }^{4}$. It is interesting to note that a similar picture was also observed in Callithrix infected with P. knowlesi (CE Tosta, G Ruiz, N Wedderburn: unpublished data).

Our frequent finding of clusters of lymphocytes, some in the process of cell division, around macrophages containing ingested parasites suggests that marginal zone macrophages may play a role in the induction of immune response to malaria parasites. Indeed, a degree of relationship between the estimated number of phagocytosing macrophages in the marginal zone and lymphocyte proliferation was found (data not shown). Although the mechanisms underlying the presentation of antigen by macrophages still remain to be established ${ }^{10}$, it has been recognised that the occurrence of lymphocyte clusters around antigen bearing macrophages in culture may lead to lymphocyte proliferation $^{2}$ and activation 7 .

Although macrophages appear to be the most important population of cells in the spleen for the removal of parasites from the circulation, other cells may also play a part, particularly reticular and interdigitating cells. However, the phagocytic ability of these cells is limited and only manifested in the presence of high parasitaemia. Their relative importance in resistance to malaria remains to be established.

\section{RESUMO}

O presente estudo objetivou investigar através de microscopia eletrônica a natureza das células esplênicas envolvidas no processo de retirada do Plasmodium berghei do sangue de camundongos $B A L B / c$ infectados e os possiveis mecanismos utilizados. Os macrófagos, particularmente da polpa vermelha e da zona marginal, constituiram a mais importante população de células fagocitárias do baço. No pico da parasitemia, macrófagos da periferia da polpa branca, principalmente da zona do manto dos folículos secundários também participaram do processo de fagocitose. Células reticulares e interdigitais também apresentaram atividade fagocitária, embora em grau limitado. Nossas observações sugerem que a fagocitose de parasitos livres e de eritrócitos parasitados constitui o principal mecanismo de destruição intra-esplênica do plasmódio. Os parasitos podem ser retirados dos eritrócitos quando estes atravessam as pequenas fendas interendoteliais 
Tosta CE, Ruiz G, Wedderburn $N$. The role of spleen macrophages in malaria: an ultrastructural study. Revista da Sociedade Brasileira de Medicina Tropical 17: 31-36, Jan-Mar, 1984

dos sinusóides e são em seguida fagocitados por macrófagos. São apresentadas evidências de que macrófagos esplênicos podem destruir parasitos através de mecanismos de citotoxicidade.

\section{Palavras-chaves: Malária. Plasmodium berghei.}

Camundongos BALB/c. Baço. Macrófagos. Fagocitose. Citotoxicidade.

\section{ACKNOWLEDGEMENTS}

The authors are grateful to Biddy Adkin, Sue Ettridge and Paulo Bezerra for expert technical assistance.

\section{REFERENCES}

1. Basten A, Mitchell $\mathbf{J}$. Role of macrophages in T-cell-B cell collaboration in antibody production. In: Nelson DS (ed) Immunobiology of the macrophage. Academic Press, New York, p. 45-90, 1976.

2. Braendstrup O, Andersen V, Werdelin O. Macrophagelymphocyte clusters in the immune response to soluble protein antigen in vitro. III. DNA synthesis of lymphocytes in clusters. Cellular Immunology 25: 207-216, 1976.

3. Chen LT, Weiss L. The role of the sinus wall in the passage of erythrocytes through the spleen. Blood 41 : $529-537,1973$.

4. Clark IA, Virelizier JL, Carswell EA, Wood PR. The possible importance of macrophage - derived mediators in acute malaria. Infection and Immunity 32: 1058-1065, 1981 .

5. Hunter KW Jr, Winkelstein JA, Simpson TW. Serum opsonic activity in rodent malaria: functional and immunochemical characteristics in vitro. Journal of Immunology 123: 2582-2587, 1979.

6. La Celle PL. Alteration of membrane deformability in hemolytic anemias. Seminars in Hematology 6: 355 $371,1970$.

7. Mitchell J, Nossal GJV. Localization and fate of foreign antigens in tissues. In: Santer $M$ (ed) Immunological Diseases, $3^{\text {rd }}$ edn, vol. I, Little Brown, Boston, p. 22-34, 1978.

8. Moran CJ, de Rivera VS, Turk JL. The immunological significance of histological changes in the spleen and liver in mouse malaria. Clinical and Experimental Immunology 13: 467-478, 1973

9. Schnitzer B, Sodeman T, Mead ML, Contacos PG. An ultrastructural study of the red pulp of the spleen in malaria. Blood 41: 207-218, 1973.

10. Steinman RM, Chen LL, Witmer MD, Kaplan G, Nussenzweig MC, Adams JC, Cohn ZA. Dendritic cells and macrophages - current knowledge of their distinctive properties and functions. In: van Furth $\mathrm{R}$ (ed) Mononuclear phagocytes. Functional aspects. Martinus Nijhoff, The Hague, p. 1781-1799, 1980.

11. Tosta CE, Wedderburn N. Immune phagocytosis of Plasmodium yoelii - infected erythrocytes by macrophages and eosinophils. Clinical and Experimental Immunology 42: 114-120, 1980 .

12. Tosta CE. The functions of macrophages in rodent malaria. PhD Thesis. University of London, London, 1981

13. Tosta CE, Hermans MAA. Atypical reticulocytes in rats with malaria as a possible consequence of the pitting function of the spleen. Annals of Tropical Medicine and Parasitology 75: 363-365, 1981.

14. Tosta CE. Effects of immune and hyperimmune serum on the dynamics of phagocytosis of Plasmodium berghei - infected erythrocytes. Revista do Instituto de Medicina Tropical de São Paulo 24: 140-147, 1982.

15. Tosta CE, Ruiz G, Wedderburn N. Effects of lethal and non-lethal malaria on the mononuclear phagocyte system. Revista da Sociedade Brasileira de Medicina Tropical 16: $58-67,1983$.

16. Weiss LP, Tavassoli M. Anatomical hazards to the passage of erythrocytes through the spleen. Seminars in Hematology 7: 372-380, 1970.

17. Wyler DJ. Cellular aspects of immunoregulation in malaria. Bulletin of the World Health Organization 57 (suppl. 1): 239-243, 1979.

18. Wyler DJ, Oster CN, Quinn TC. The role of the spleen in malaria infections. In: The role of the spleen in the immunology of parasitic diseases. W. H. O. Tropical Diseases Research Series no 1. Schwabe, Basel, p. $183-204,1979$.

19. Wyler DJ. Splenic functions in malaria. Lymphology 16 : 121-127, 1983. 